\section{TUTORIAL BISNIS}

\section{CHATBOT LINE Q}

Chatbot adalah layanan yang memungkinkan pengguna berkomunikasi dengannya menggunakan antarmuka obrolan. Dengan cara yang sama seperti anda bertanya kepada seseorang, Anda dapat mengajukan pertanyaan menggunakan suara anda atau dengan mengetik. Dalam kebanyakan kasus, chatbot akan menjawab dengan cara percakapan, dan mungkin melakukan tindakan sebagai tanggapan atas percakapan anda misalnya sebagai pengganti customer service dalam bisnis anda.

Line adalah aplikasi media sosial diluncurkan pada Juni 2011, LINE diklaim sebagai aplikasi pengirim pesan instan popular dibeberapa negara, LINE dapat digunakan pada berbagai platform seperti iOS, Android, Windows Phone, BlackBerry OS, Mac OS X, dan Microsoft Windows. Apa yang membedakan LINE dari jejaring sosial lain adalah berbagai fitur dan alat yang ditawarkannya. Selain olahpesan seluler, panggilan suara, dan panggilan video, LINE mengintegrasikan alat untuk perbankan, belanja, dan lainnya. Aplikasi ini juga memusatkan akses ke layanan kesehatan, agen perjalanan, restoran dan toko, dan lowongan pekerjaan.

Buku ini merupakan sebuah buku panduan atau Langkah-langkah sederhana dalam membuat chatbot pada media sosial LINE yang dapat digunakan oleh pendatang baru dalam berbisnis, UMKM, Mahasiswa serta pembaca lainnya dalam memahami dan mampu untuk membuat chatbot sebagai penganti customer service ataupun untuk memperkenalkan produk atau berkaitan dengan bisnis yang anda kelola melalui media social LINE.

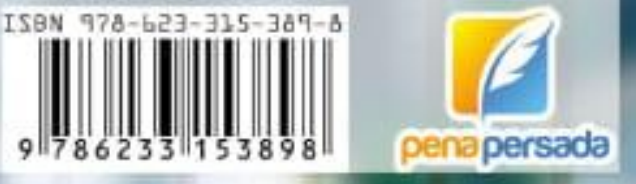

Hendra Mayatopani Wahyu Tisno Atmojo,

Erick Dazki * Nadda Akilka

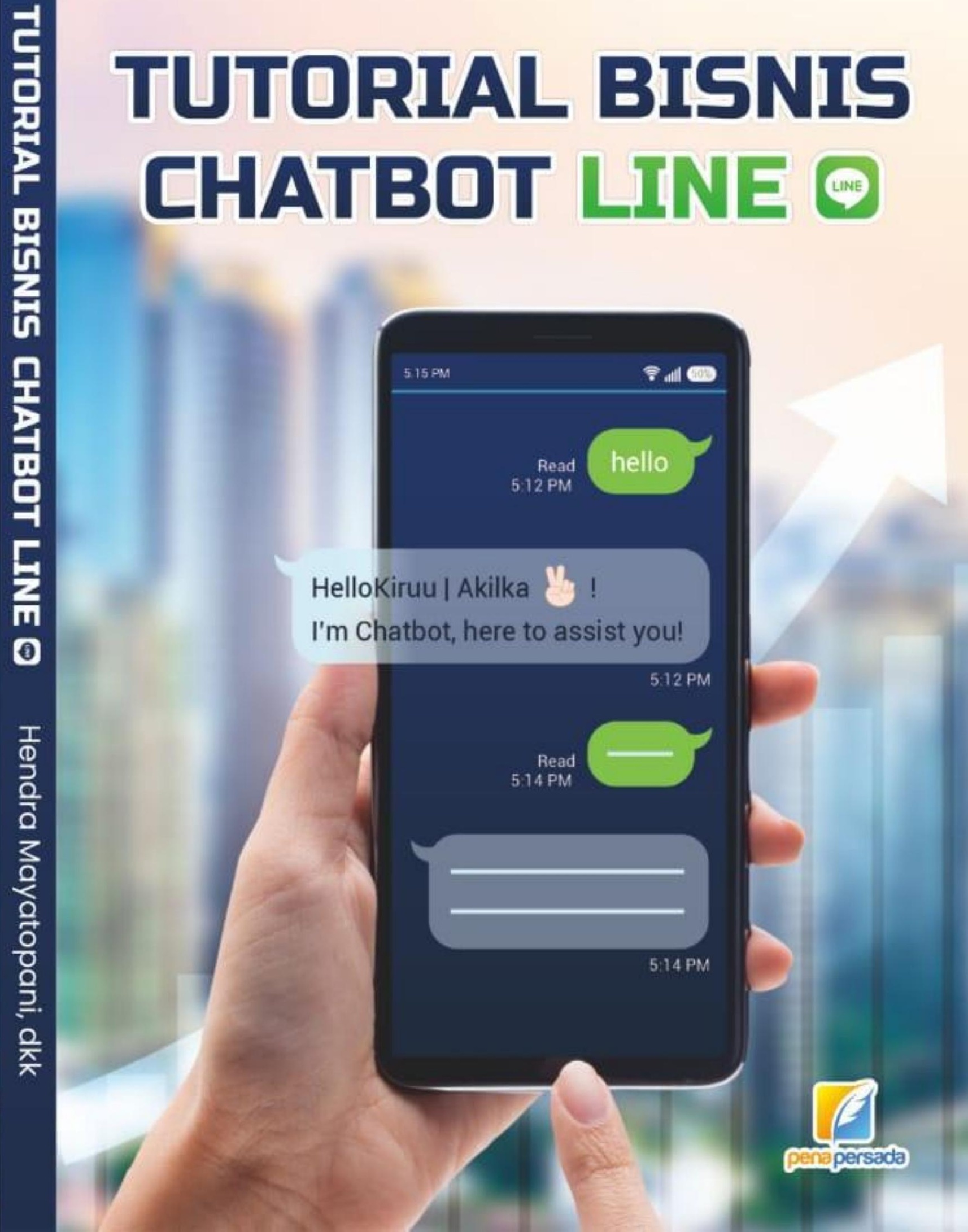




\section{Tutorial Bisnis Chatbot Line}

Hendra Mayatopani, Wahyu Tisno Atmojo, Erick Dazki,

Nadda Akilka

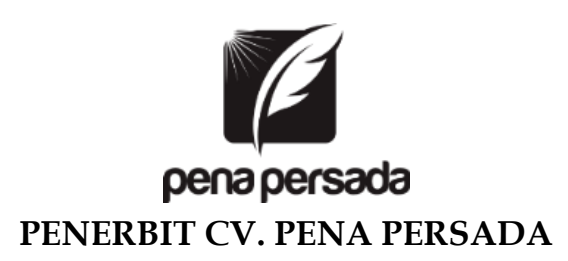




\section{Tutorial Bisnis Chatbot Line}

Penulis:

Hendra Mayatopani, Wahyu Tisno Atmojo, Erick Dazki, Nadda Akilka

ISBN : 978-623-315-389-8

Design Cover :

Retnani Nur Briliant

Layout :

Eka Safitry

\section{Penerbit CV. Pena Persada}

Redaksi :

Jl. Gerilya No. 292 Purwokerto Selatan, Kab. Banyumas

Jawa Tengah

Email : penerbit.penapersada@gmail.com

Website : penapersada.com Phone : (0281) 7771388

\section{Anggota IKAPI}

All right reserved

Cetakan pertama : 2021

Hak Cipta dilindungi oleh undang-undang. Dilarang memperbanyak karya tulis ini dalam bentuk apapun tanpa izin penerbit 


\section{KATA PENGANTAR}

Pertama-tama kami panjatkan puji dan syukur kepada ALLAH SWT yang telah memberikan sebuah nikmat ilmu dan sehat kepada penulis dalam menyelesaikan buku ini dan terima kasih kepada universitas pradita dan Lembaga penelitian dan pengabdian masyarakat univ pradita.

Terima kasih kepada Penerbit CV.PENAPERSADA yang sudah memberikan kesempatan penulis dalam menerbitkan buku ini.

Tujuan penulis dalam melakukan tulisan ini memberikan sebuah masukan kepada pelaku bisnis dalam dunia digital 24/7 sebagai peran pengganti customer service dengan sebuah chatbot yang mudah digunakan dan menciptakan salah satu peluang bisnis dalam memasarkan sebuah produk pada media sosial line, chatbot ini dibuat melalui media sosial line yang salah satunya digunakan oleh orang Indonesia.

Semoga para pembaca mendapat banyak manfaat dari ulasan buku ini dan berguna dalam membangun usaha bisnis dalam persaingan dunia digital.

Jakarta, 2021

Penulis 


\section{DAFTAR ISI}

KATA PENGANTAR iii

DAFTAR ISI

Daftar Gambar $\quad$ V

BAGIAN I Download dan Register Line 1

A. Download LINE 1

B. Register Line Business Account 5

BAGIAN II Line Account Developer 8

A. LINE Business ID 8

BAGIAN III LINE Account Manager 14

A. Account 14

B. Greeting Message 15

C. Auto-response Messages 16

D. Rich Messages 18

E. Rich Video Messages 23

F. Card-Based Messages 27

G. Rich Menus 31

H. Coupons 37

I. Reward Cards 40

J. Surveys 46

K. Gain Friends $\quad 50$

L. Tracking LINE Tags 50

BAGIAN IV Implementasi $\quad 51$

A. Greeting Message 51

B. Auto-response message 51

C. Card-Based Message 52

D. Rich Menu 53

DAFTAR PUSTAKA 55

PENULIS 56 


\section{Daftar Gambar}

Gambar 1.1. 1. Halaman LINE Official 1

Gambar 1.1. 2. Halaman Download LINE 1

Gambar 1.1. 3. Instalasi LINE Desktop 1

Gambar 1.1. 4. Instalasi LINE Desktop 2

Gambar 1.1. 5. Instalasi LINE Desktop 3

Gambar 1.1. 6. Instalasi LINE Desktop 4

Gambar 1.1. 7. Instalasi LINE Desktop 5

Gambar 1.2. 1. LINE Business ID 5

Gambar 1.2. 2. Create an Account 1

Gambar 1.2. 3. Create an Account $2 \quad 6$

Gambar 1.2. 4. Create an Account $3 \quad 6$

Gambar 1.2. 5. Signup Business Account $\quad 7$

Gambar 1.2. 6. Hasil Business Account 7

Gambar 2. 1. Halaman Utama Developer 8

Gambar 2. 2. Verifikasi Akun LINE 9

Gambar 2. 3. LINE Developers - Providers 9

Gambar 2. 4. Membuat Provider Baru 10

Gambar 2. 5. Membuat Messaging API Channel 10

Gambar 2. 6. Create a Channel 11

Gambar 2. 7. Memasukkan Nama dan Deskripsi Channel 11

Gambar 2. 8. Memilih Category dan Subcategory Channel 12

Gambar 2. 9. LINE Official Account Terms of Use 12

Gambar 2. 10. Halaman utama LINE Developers Chatbot 13

Gambar 3.1. 1. Tampilan LINE Official Account Manager 14

Gambar 3.1. 2. Halaman utama menu LINE Account Manager 14

Gambar 3.2. 1. Tampilan Greeting Message 15

Gambar 3.2. 2. Pesan Default Greeting Message 15

Gambar 3.3. 1. Tampilan Utama Auto-Response Messages 16

Gambar 3.3. 2. Isi Auto-Response Message 1

Gambar 3.3. 3. Isi Auto-Response Message 2

Gambar 3.3. 4. Pilihan Konten Auto-Response Message 17

Gambar 3.3. 5. Pesan-Pesan Auto-Response yang Sudah Dibuat 18

Gambar 3.4. 1. Tampilan Utama Rich Messages 18

Gambar 3.4. 2. Memmbuat Rich Message 19 
Gambar 3.4. 3. Memilih Template Pesan Rich Message

Gambar 3.4. 4. Upload Image Rich Message 20

Gambar 3.4. 5. Create Image Rich Message 1

Gambar 3.4. 6. Create Image Rich Message 2

Gambar 3.4. 7. Create Image Rich Message $3 \quad 21$

Gambar 3.4. 8. Memilih Action Rich Message 22

Gambar 3.4. 9. Mengisi Link dan Label Action Message 22

Gambar 3.4. 10. Tampilan Daftar Rich Messages yang Telah

Dibuat 23

Gambar 3.5. 1. Tampilan Utama Rich Video Messages 23

Gambar 3.5. 2. Membuat Rich Video Message 24

Gambar 3.5. 3. Mengupload Video Pesan Rich Video 24

Gambar 3.5. 4. Ukuran Video Pesan Rich Video 25

Gambar 3.5. 5. Pengaturan Action Button 25

Gambar 3.5. 6. Pengaturan Action Button Label 26

Gambar 3.5. 7. Daftar Rich Video Messages yang Telah Dibuat 26

Gambar 3.6. 1. Tampilan Utama Card-Based Message 27

Gambar 3.6. 2. Membuat Card-Based Message 27

Gambar 3.6. 3. Memilih Tipe Kartu 28

Gambar 3.6. 4. Mengisi Pesan Kartu 28

Gambar 3.6. 5. Card-Based Message Menggunakan Banner 29

Gambar 3.6. 6. Card-Based Message Tanpa Banner 29

Gambar 3.6. 7. Memilih Action Type 30

Gambar 3.6. 8. Closing Card $\quad 30$

Gambar 3.7. 1 Tampilan Utama Rich Menu 31

Gambar 3.7. 2. Membuat Rich Menu 1

Gambar 3.7. 3. Membuat Rich Menu 2 32

Gambar 3.7. 4. Menu Content $\quad 32$

Gambar 3.7. 5. Create Image 1

Gambar 3.7. 6. Menambah Text untuk Menu 33

Gambar 3.7. 7. Mewarnai Background Menu $\quad 34$

Gambar 3.7. 8. Create Image 2

Gambar 3.7. 9. Membuat Menu Bagian Kanan 35

Gambar 3.7. 10. Action Type dan Action Label 1

Gambar 3.7. 11. Action Type dan Action Label 2

Gambar 3.7. 12. Daftar Rich Menu yang Telah Dibuat 36 
Gambar 3.8. 1. Tampilan Utama LINE Coupons

Gambar 3.8. 2. Create Coupon 37

Gambar 3.8.3. Title, Validity Period, Image, dan Coupon Guidelines 38

Gambar 3.8. 4. Coupon Advanced Settings 38

Gambar 3.8. 5. Share Coupon $\quad 39$

Gambar 3.8. 6. Daftar Coupon yang Telah Dibuat 39

Gambar 3.9. 1. Tampilan Reward Cards 40

Gambar 3.9. 2. Select Voucher $\quad 41$

Gambar 3.9. 3. Create Voucher 41

Gambar 3.9. 4. Konfirmasi Create Voucher 42

Gambar 3.9. 5. Pilih Voucher 42

Gambar 3.9. 6. Menentukan Expiration Date dan Reminder 43

Gambar 3.9. 7. Save Reward Cards 44

Gambar 3.9. 8. Konfirmasi Publish Reward Card 44

Gambar 3.9. 9. Distribute Card 45

Gambar 3.10. 1 Tampilan Utama Surveys $\quad 46$

Gambar 3.10. 2. Create Survey $\quad 47$

Gambar 3.10. 3. Basic Setting Survey $\quad 47$

Gambar 3.10. 4. Intro Page Setting 48

Gambar 3.10. 5. Thank-you Page 48

Gambar 3.10. 6. Question Settings dan Custom Settings 49

Gambar 3.10. 7. Daftar Surveys yang Telah Dibuat 49

Gambar 3.11. 1 Tampilan Utama Gain Friends $\quad 50$

Gambar 3.12. 1 Tampilan Utama Tracking (LINE Tags) 50

Gambar 4.1.1. Greeting Message 51

Gambar 4.1. 2. Auto-response Message 51

Gambar 4.1. 3. Card-Based Message Tope Image 52

Gambar 4.1. 4. Card-Based Message Tipe People dan Closing

Card 52

Gambar 4.1. 5. Auto-Response Message di Rich Menu untuk Rich

Message 53

Gambar 4.1. 6. Auto-Response Message di Rich Menu untuk Rich Video 
Tutorial Bisnis Chatbot Line 


\section{BAGIAN I \\ Download dan Register Line}

\section{A. Download LINE}

Kunjungi https://line.me/ dan klik download di pojok kiri atas halaman

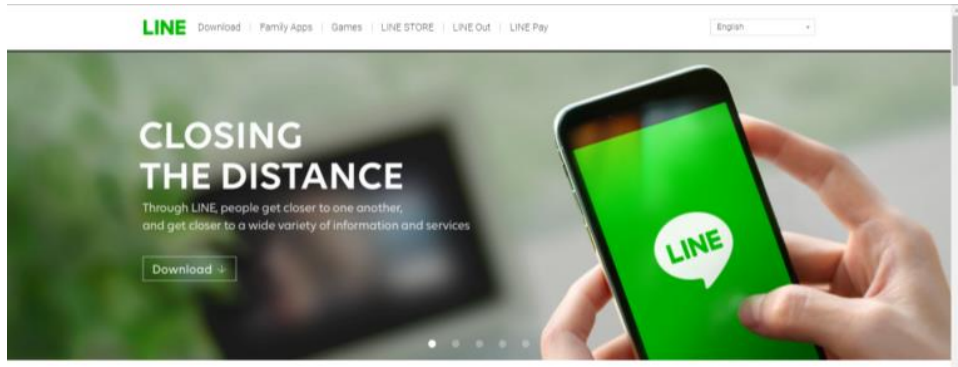

Gambar 1.1. 1. Halaman LINE Official

Kemudian pilih Get LINE for Windows

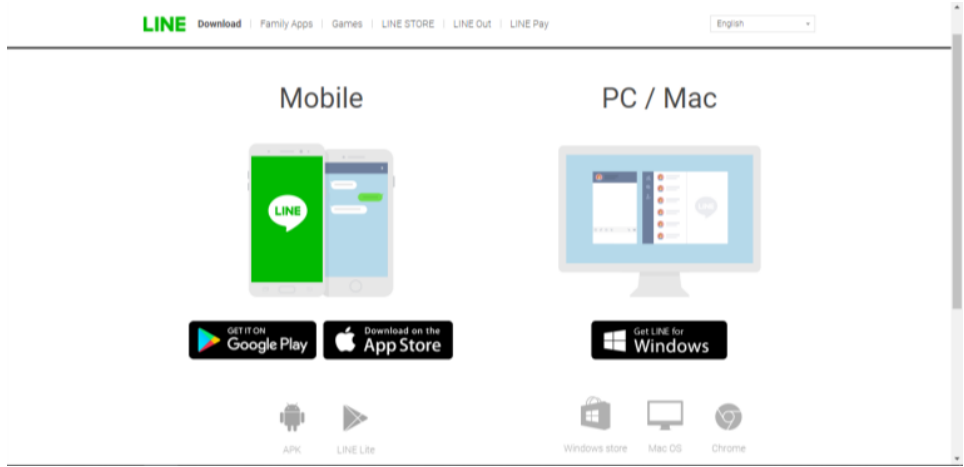

Gambar 1.1. 2. Halaman Download LINE 
Setelah selesai mendownload, klik hasil download tadi. Kemudian klik Run.

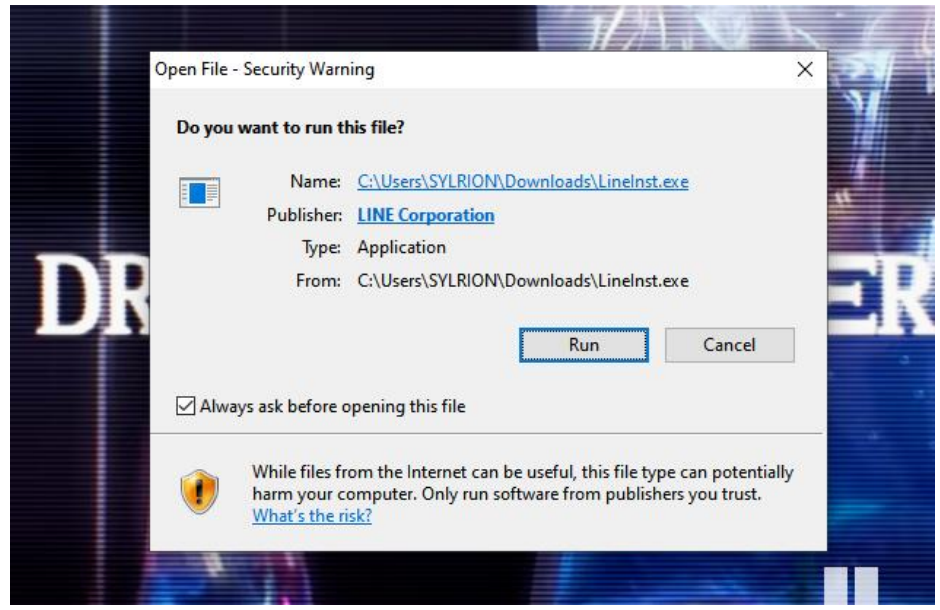

Gambar 1.1. 3. Instalasi LINE Desktop 1

Pilih bahasa yang diinginkan, klik Next, dan I Agree.

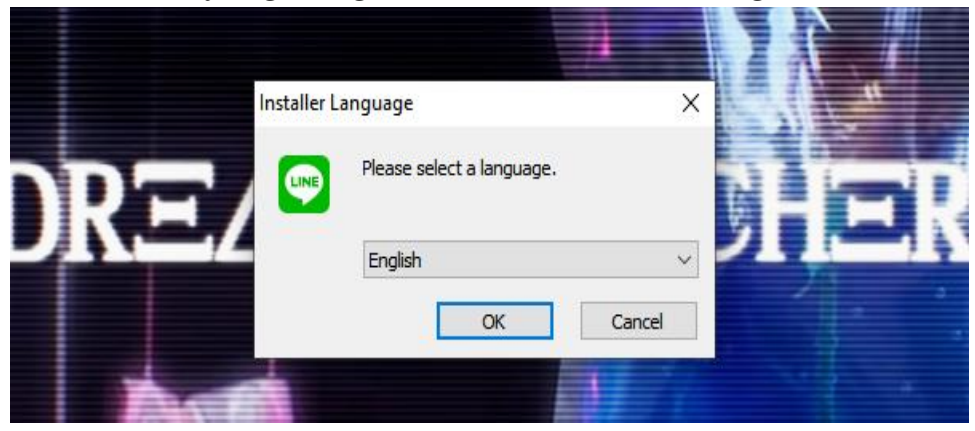

Gambar 1.1. 4. Instalasi LINE Desktop 2 


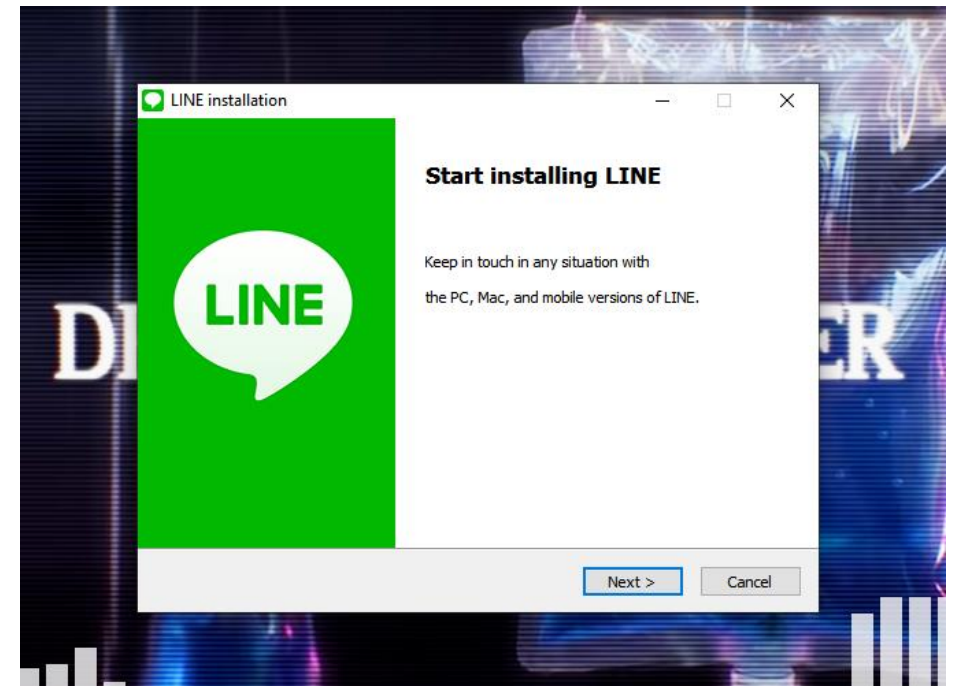

Gambar 1.1. 5. Instalasi LINE Desktop 3

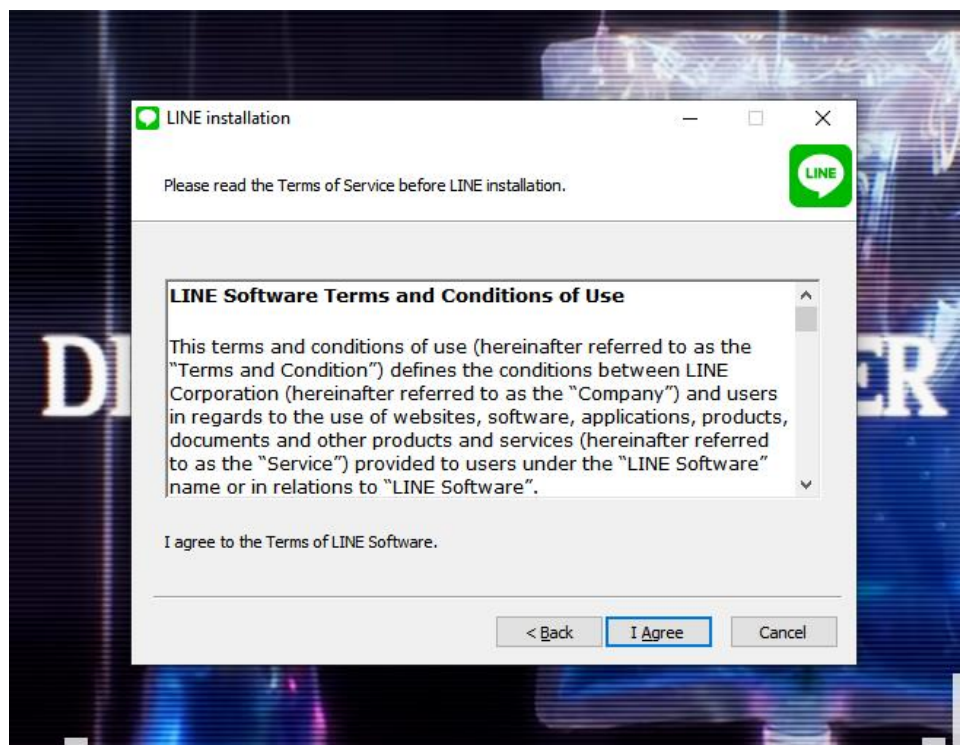

Gambar 1.1. 6. Instalasi LINE Desktop 4 
Tunggu beberapa saat dan instalasi berhasil.

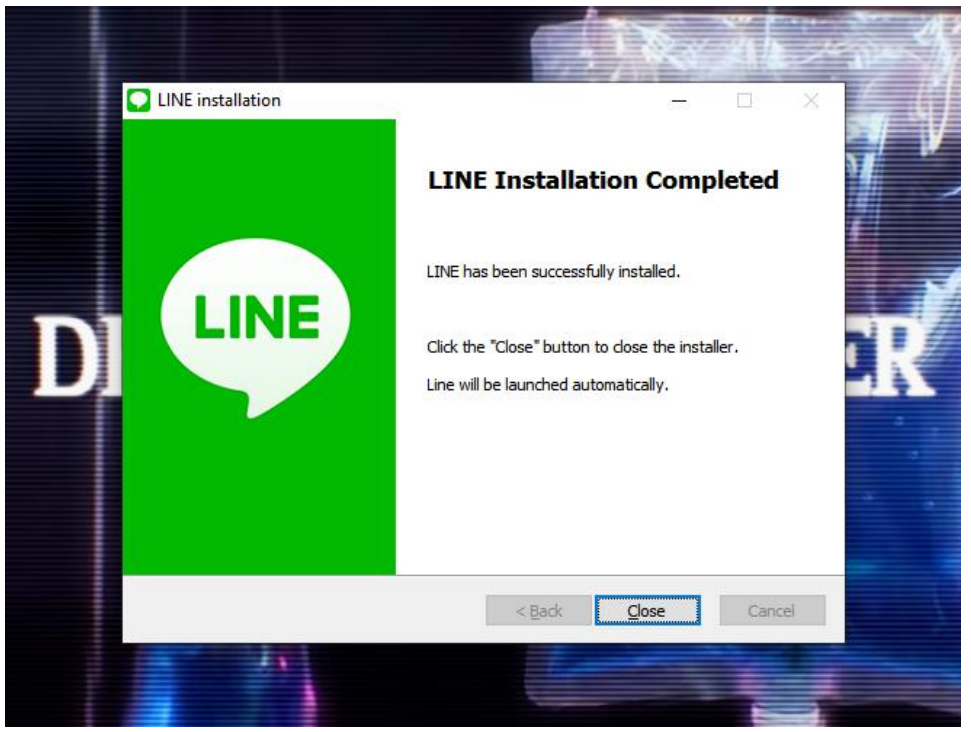

Gambar 1.1. 7. Instalasi LINE Desktop 5 


\section{B. Register Line Business Account}

Pergi menuju https://account.line.biz/signup untuk register Business Account. Kemudian klik Create an account.

\section{LINE Business ID}

\section{Log in with LINE account}

or

Log in with business account

Create an account

By logging in to LINE Business ID, you agree to the Terms of Use.

(3) About LINE Business ID

English - Help Terms of Use @ LINE Corporation

\section{Gambar 1.2. 1. LINE Business ID}

Masukkan email yang ingin digunakan, dan klik Send signup link.

\section{LINE Business ID}

\section{Sign up with LINE account}

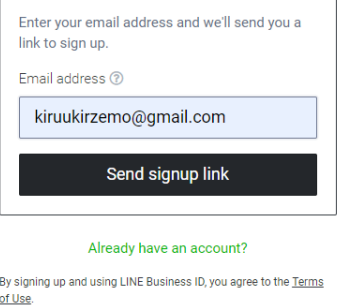

of use

Gambar 1.2. 2. Create an Account 1 
LINE akan mengirimkan anda link untuk membuat akun. Anda nanti akan mendapatkan notifikasi seperti yang ditunjukkan oleh panah merah.

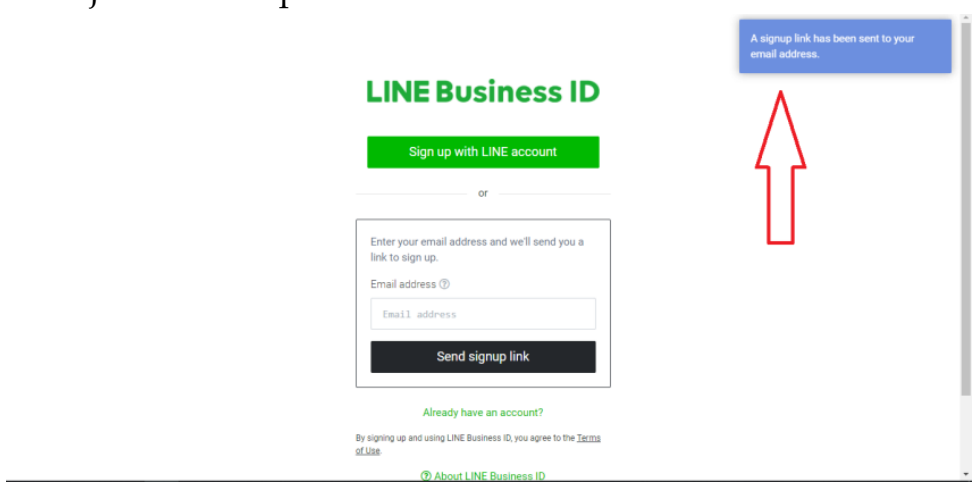

\section{Gambar 1.2. 3. Create an Account 2}

Selanjutnya anda perlu mengecek email yang tadi didaftarkan. LINE akan mengirimkan anda email seperti gambar 1.2.4. Klik Continue. Anda nanti akan diberikan tampilan seperti gambar 1.2.5.

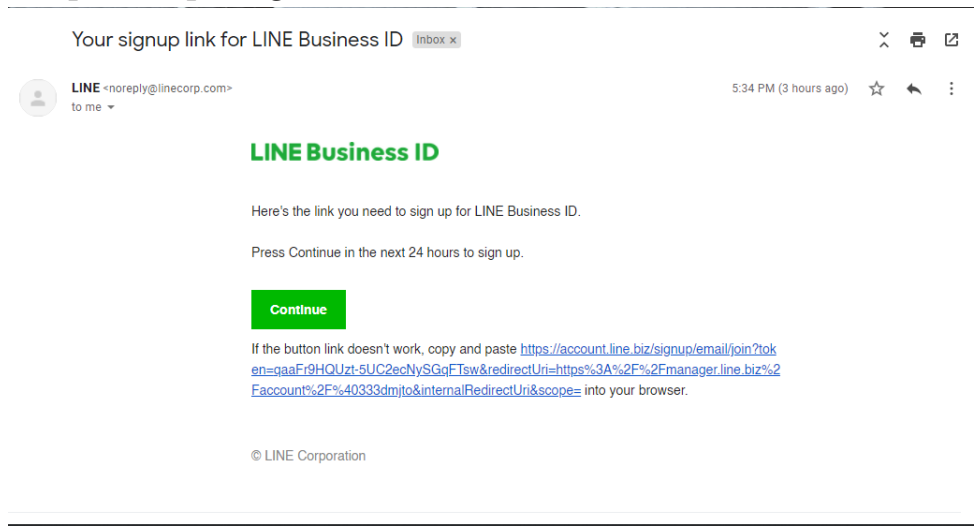

\section{Gambar 1.2. 4. Create an Account 3}

Langkah terakhir adalah dengan mengisi nama, password, dan mengisi captcha. Ketika sudah selesai silakan untuk klik sign up, dan anda telah berhasil membuat akun bisnis LINE. 
Anda boleh menggunakan Business Account untuk pembuatan chatbot, atau menggunakan akun LINE pribadi yang sudah pernah dibuat. Jika ingin menggunakan Business Account, silakan klik Sign up sesuai di gambar 1.2.6.

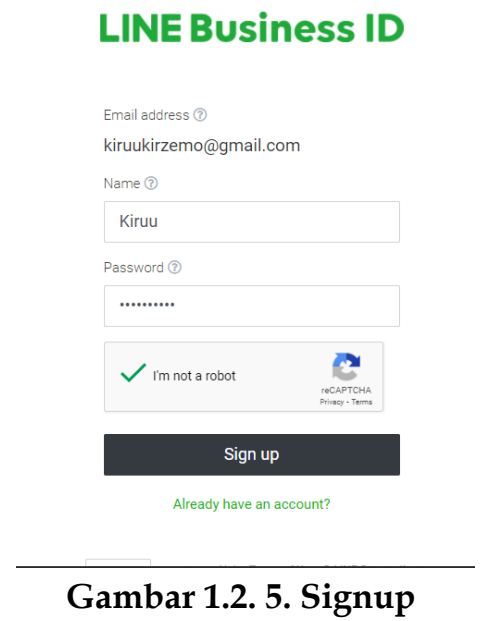

Business Account

\section{LINE Business ID}

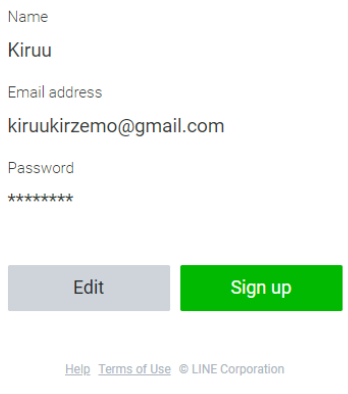

Gambar 1.2. 6. Hasil

Business Account 


\section{BAGIAN II \\ Line Account Developer}

\section{A. LINE Business ID}

\section{LINE Business ID}

\section{Log in with LINE account}

or

Log in with business account

Create an account

By logging in to LINE Business ID, you agree to the Terms of Use.

?? About LINE Business ID

English -

\section{Gambar 2. 1. Halaman Utama Developer}

Anda dapat login dengan menggunakan akun line atau dengan login akun bisnis yang sudah dibuat di tutorial sebelumnya.

Biasanya saat login dengan akun line biasa yang telah terdaftar, anda akan diminta untuk verifikasi akun anda dengan memasukkan nomor yang tertera di layar desktop ke akun line anda (bisa verifikasi lewat line smartphone atau desktop. 


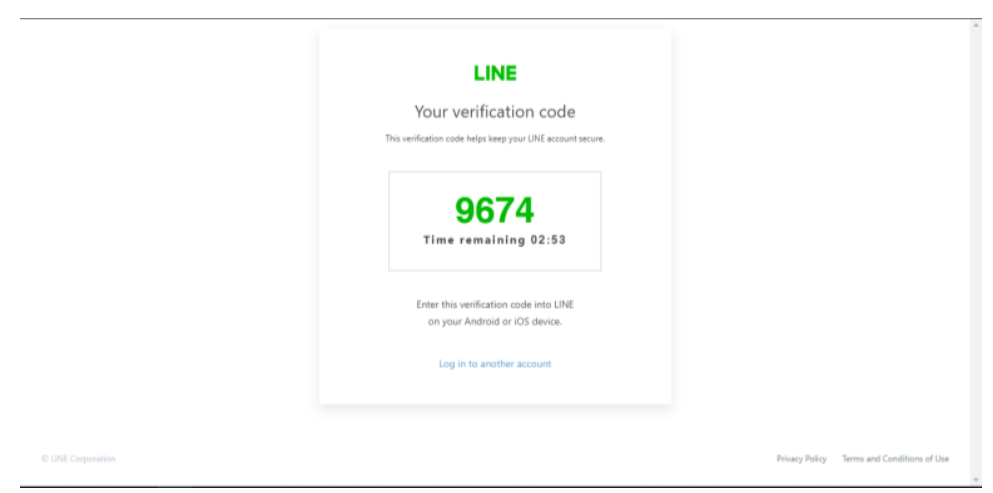

\section{Gambar 2. 2. Verifikasi Akun LINE}

Anda kemudian akan dihadapkan dengan tampilan line developers. Klik create untuk membuat provider baru, dan anda akan diminta untuk membuat nama provider. Nama provider bebas sesuai keinginan anda.

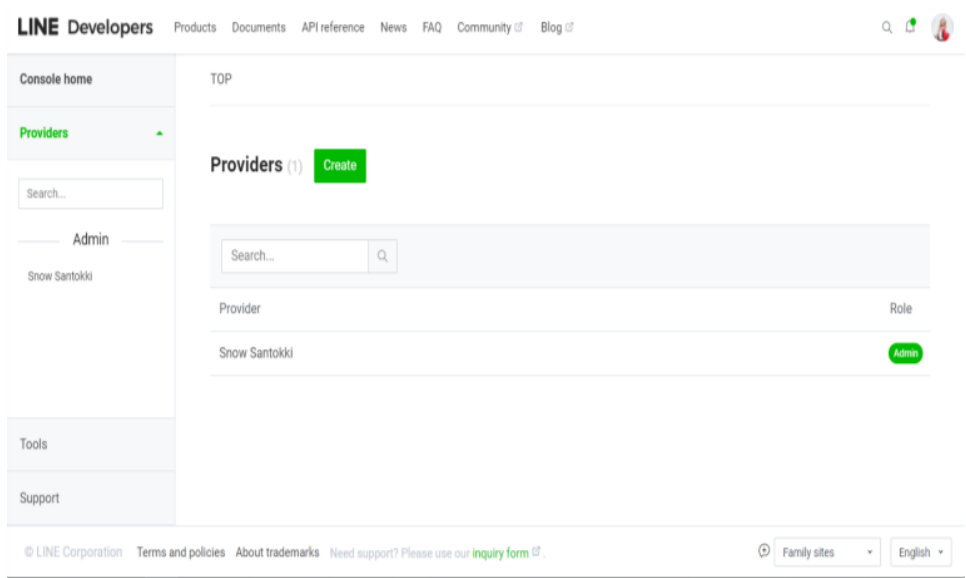

Gambar 2. 3. LINE Developers - Providers 


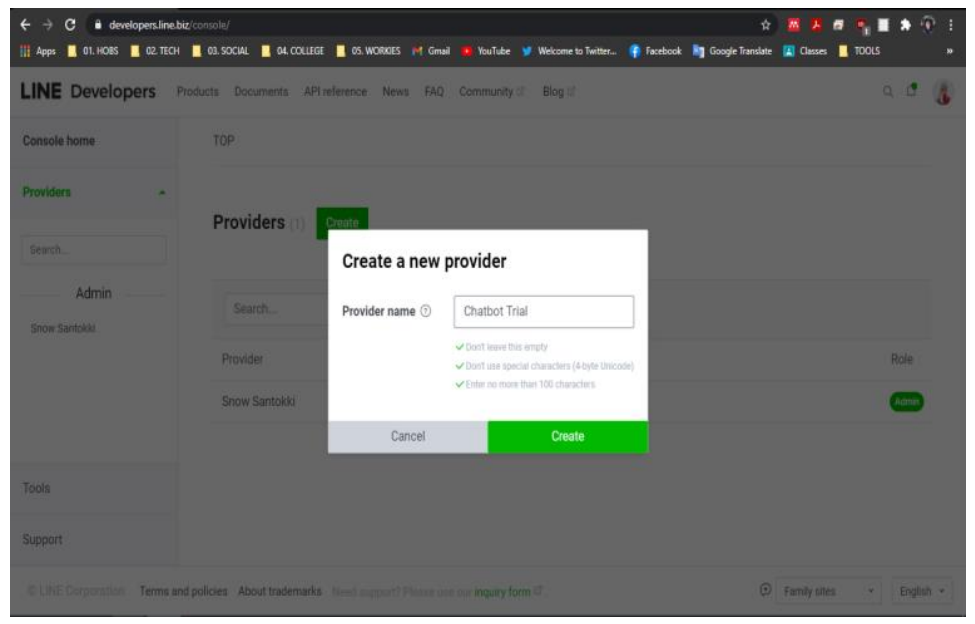

Gambar 2. 4. Membuat Provider Baru

Selanjutnya, klik Create a Messaging API channel

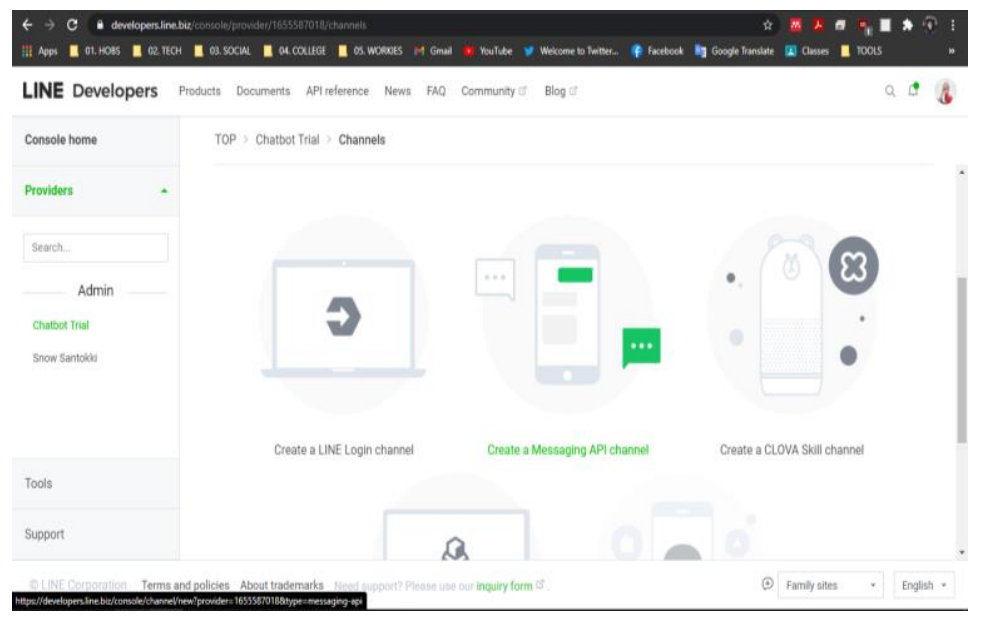

Gambar 2. 5. Membuat Messaging API Channel 
Setelah itu anda akan melihat halaman seperti gambar di bawah ini.

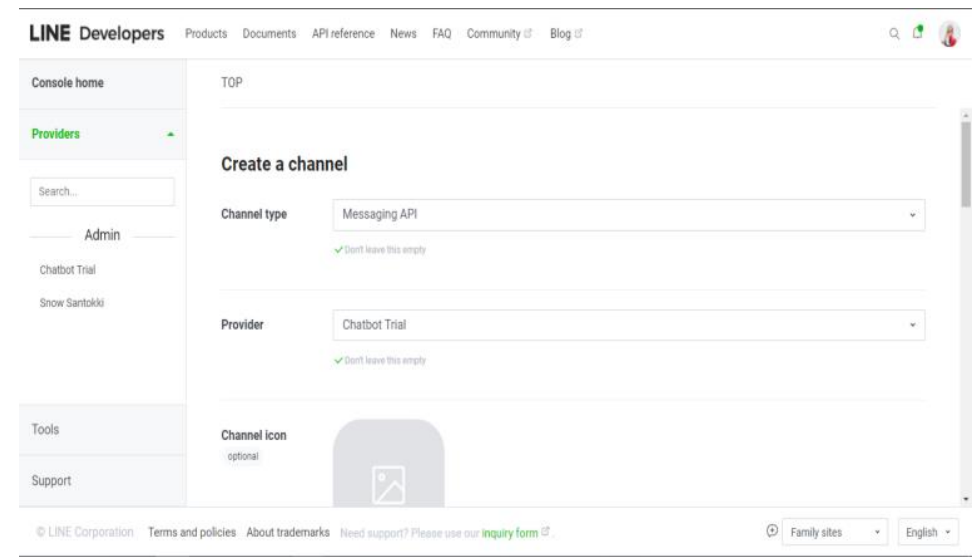

Gambar 2. 6. Create a Channel

Buatlah nama channel dan masukkan deskripsi channel.

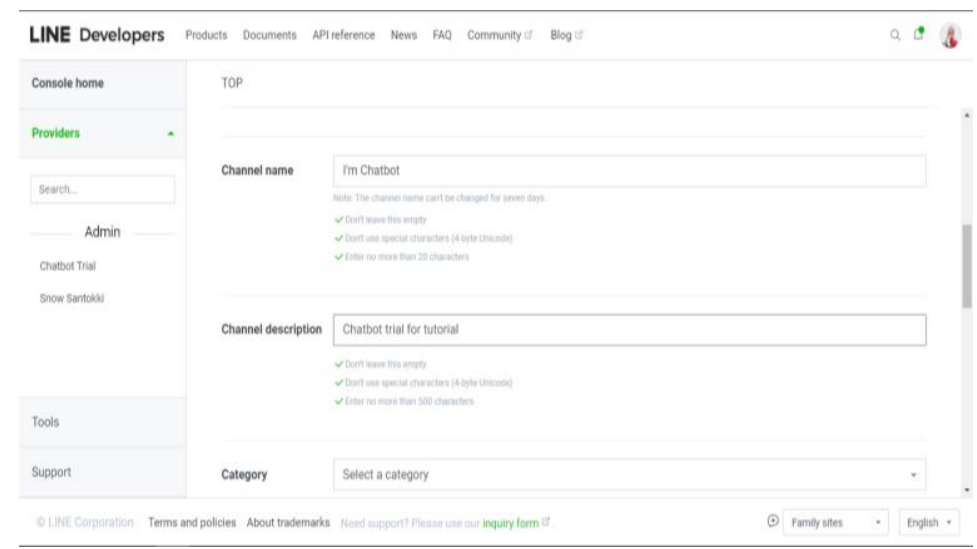

Gambar 2. 7. Memasukkan Nama dan Deskripsi Channel

Langkah berikutnya adalah memilih kategori dan subkategori channel. Kategori channel dipilih sesuai dengan tujuan chatbot line dibuat. Untuk tutorial kali ini, kategori yang dipilih adalah "Sekolah dan Universitas". 